\section{Effects of Follicular Fluid on Developmental Competence and Gene Expression of in vitro Fertilized Sheep Embryos}

\author{
Mousa O. Germoush" ${ }^{1 *}$, Mohsen G. Al-Mutary ${ }^{2}$, Ahmad R. Al-himaidi $^{3}$, \\ Muath G. Al-Ghadi ${ }^{3}$, Daisaku Iwamoto ${ }^{3,4}$, Yousef Al-anazi ${ }^{3}$, Aiman Ammari ${ }^{3}$, \\ Javed Ahmad ${ }^{3,5}$, Abdulaziz Al-Khedhairy ${ }^{3,5}$ \\ ${ }^{1}$ Department of Biology, College of Science, Aljouf University, Sakaka, Al Jouf, \\ Saudi Arabia \\ ${ }^{2}$ Basic Sciences Department, College of Education, Imam Abdulrahman Bin Faisal \\ University, Dammam, Saudi Arabia \\ ${ }^{3}$ Department of Zoology, College of Science, King Saud University, Riyadh, Saudi \\ Arabia \\ ${ }^{4}$ Deptartement of Genetic Engineering, Faculty of Biological-Oriented Science and \\ Technology, Kinki University, Wakayama, Japan \\ ${ }^{5}$ Chair for DNA Research, Department of Zoology, College of Science, King Saud \\ University, Riyadh, Saudi Arabia
}

\section{A B S T R A C T}

This study was undertaken to evaluate the effect of follicular fluid supplementation on the oocyte in vitro maturation and early embryonic development after in vitro fertilization. Sheep follicular fluid (SFF) was collected from different ovaries and supplemented to the in vitro maturation (IVM) media with proportions $0 \%, 10 \%, 20 \%$ and $40 \%$. Oocyte maturation was assessed in different treatments and then cumulus-oocyte complexes were used for in vitro fertilization. Relative quantitative expression of mRNA transcripts related to apoptosis (Bax and Bcl-2), embryo development (LAMA1, IL-6 and FGF4) and stress (HSPB1) were examined. The results showed that $10 \%$ and $20 \%$ SFF supplementation exerted no effect on maturation and cleavage percentage whereas $40 \%$ SFF supplementation significantly decreased maturation and cleavage. SFF supplemented at $10 \%$ concentration showed a significant increase in blastocyst development when compared with other groups. Gene expression analysis revealed a significant increase in BAX expression in groups supplemented with SFF $20 \%$ and $40 \%$, whereas the expression of BCL-2 was significantly increased only in the $40 \%$ SFF supplemented group. The ratio of Bax to Bcl-2 was significantly increased in the embryos derived from oocytes matured in $20 \%$ and $40 \%$ SFF supplemented media. HSPB1 expression was significantly increased in group matured in $20 \% \mathrm{SFF}$. The relative expression of IL-6, LAMA1 and FGF4 genes did not show any difference between groups. In conclusion, IVM medium supplemented with 10\% SFF showed the best rate of blastocyst development.
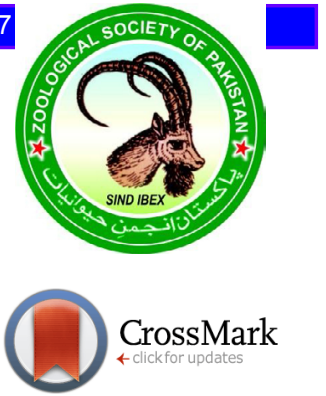

\section{INTRODUCTION}

$\mathrm{T}$ he modification of in vitro maturation (IVM) media to imitate the in vivo and to support the maturation of oocytes is important for in vitro embryo production (IVEP) in animals (Lanzendorf et al., 1996; Dell'Aquila et al., 1997; Coleman et al., 2007). Thus, several substances have been supplemented to improve the culture conditions of the IVM. One of these substances is the follicular fluid (FF) that has various nutrients that may affect oocyte

* Corresponding author: mogermoush@ju.edu.sa 0030-9923/2018/0004-1267 \$9.00/0

Copyright 2018 Zoological Society of Pakistan growth, fertilization, and embryo development (Tabatabaei and Mamoei, 2011; Duarte et al., 2012).

FF was used during IVM in cattle (Larocca et al., 1993; Kim et al., 1996; Ali et al., 2004), human (Chi et al., 1998), goat (Cognie et al., 2003; Masudul et al., 2012), pig (Huang et al., 2002; Ito et al., 2008), buffalo (Nandi et al., 2004; Gupta et al., 2005), horse (Bogh et al., 2002), and sheep (Sun et al., 1994). However, supplementation of the FF to the in vitro maturation media can lead to changes in mRNA abundance, influencing gene expression not only in the oocytes but also in the blastocyst stages (Watson et al., 2000; Young et al., 2001; Lonergan et al., 2003; Wrenzycki et al., 2005; Cruz et al., 2014). In general, the competence of oocyte is evaluated by maturation 
rate, fertilization rate, cleavage rate and blastulation ratio (Iwata et al., 2004). In addition, analysis of expression patterns of developmentally important genes can be used as good markers of the quality of embryos (Li et al., 2009). To date, the effect of sheep follicular fluid (SFF) supplementation during the in vitro maturation of sheep oocytes on gene expression and embryo development has not been investigated. In the present study, we evaluated the effect of SFF on oocyte maturation, pointing to changes in the expression of genes related to apoptosis (Bax and Bcl-2), embryo development (LAMA1, IL-6 and FGF4) and stress (HSPB1).

\section{MATERIALS AND METHODS}

\section{Chemicals and reagents}

All the chemicals and media used in the present study were from Sigma-Aldrich (St. Louis, MO, USA) unless otherwise noted.

\section{Collection and preparation of SFF}

Mixed SFF was collected from ovaries that were brought from local slaughter house. The follicular fluid was aspirated by an 18 gauge needle attached to a $10 \mathrm{ml}$ syringe and was pooled in a $15 \mathrm{ml}$ tubes and centrifuged twice at $4000 \mathrm{rpm}$ for $20 \mathrm{~min}$ to remove granulosa cells, blood cells and oocytes. The supernatants were collected, filtered by $0.45 \mu \mathrm{m}$ filter. The SFF was heat-inactivated at $56^{\circ} \mathrm{C}$ for $30 \mathrm{~min}$, aliquoted in $1.5 \mathrm{ml}$ tube and stored at $-20^{\circ} \mathrm{C}$ until use. All experiments were performed with the same batch.

\section{Oocyte collection and IVM}

Ovaries were collected from central slaughterhouse in Riyadh (Saudi Arabia) and transported within $2 \mathrm{~h}$ to the laboratory in $0.9 \% \mathrm{NaCl}$. The cumulus oocyte complexes (COCs) were obtained by aspiration using a sterile syringe onto $0.5 \mathrm{ml}$ handling medium TCM-199 (Hank's salts) supplemented with $10 \%$ FCS, $0.5 \mathrm{mM} \mathrm{Na-Pyruvate,} 140$ $\mu \mathrm{g} / \mathrm{ml}$ heparin and $50 \mu \mathrm{g} / \mathrm{ml}$ gentamycin. The oocytes with or more than three layers of intact cumulus cells and uniform cytoplasm were collected under a stereomicroscope by mouth pipette. The COCs were then washed three times in $100 \mu \mathrm{l}$ of maturation medium TCM-199 (Earle's salts) with $10 \%$ FCS, $0.5 \mathrm{mM} \mathrm{Na-Pyruvate,} 0.02 \mathrm{IU} / \mathrm{ml}$ folliclestimulating hormone (FSH), $0.023 \mathrm{IU} / \mathrm{ml}$ luteinizing hormone (LH), $1 \mu \mathrm{g} / \mathrm{ml} \mathrm{E} 2,100 \mu \mathrm{M}$ cystamine, $50 \mu \mathrm{g} /$ ml gentamycin and 0\% SFF (Control: Group A), 10\% SFF (Group B), 20\% SFF (Group C) or 40\% SFF(Group D). Then, groups of ten COCs were placed in $50 \mu$ l maturation drops which was covered with mineral oil and incubated in a $100 \%$ humidified atmosphere and $5 \% \mathrm{CO}_{2}$ for $24 \mathrm{~h}$ at $38.5^{\circ} \mathrm{C}$. Following incubation, samples of oocytes from each group were denuded from cumulus cells and mounted on slides, fixed in acetic acid:ethanol 3:1 (v/v) for $24 \mathrm{~h}$, then stained with $1 \%$ aceto-orcein. The oocytes were examined using a phase contrast microscope $(400 \mathrm{x}$ Olympus, CKX41 Japan) and assessed for oocyte nuclear status.

\section{In vitro fertilization of oocytes}

Fresh semen from ram was collected and washed in capacitation medium HEPES-Tyrode's Albumin Lactate Pyruvate (Caisson Labs, IVL02, USA) containing $6 \mathrm{mg} / \mathrm{ml}$ bovine serum albumin (BSA), $50 \mu \mathrm{g} / \mathrm{ml}$ gentamicin and $0.5 \mathrm{mM}$ Na-pyruvate, centrifuged twice at $1800 \mathrm{rpm}$ for 5 min. For swim up, $0.5 \mathrm{ml}$ of semen was kept under $1 \mathrm{ml}$ of capacitation medium in a $15 \mathrm{ml}$ conical Falcon tube at $38.5^{\circ} \mathrm{C}$ for one hour. Before transfer to fertilization drops, the oocytes were washed four times in IVF-Tyrode's Albumin Lactate Pyruvate (Caisson Labs, IVL01, USA) with $6 \mathrm{mg} / \mathrm{ml} \mathrm{BSA,} 140 \mu \mathrm{g} / \mathrm{ml}$ heparin and $50 \mu \mathrm{g} / \mathrm{ml}$ gentamycin. Insemination was carried out by adding $2.0 \times 10^{6}$ into fertilization medium that included 10 oocytes per $50 \mu \mathrm{l}$ fertilization drop in an atmosphere of $5 \% \mathrm{CO}_{2}$ and humidified air at $38.5^{\circ} \mathrm{C}$ for $24 \mathrm{~h}$.

\section{In vitro culture of embryos}

After IVF, zygotes were denuded from cumulus cells by pipetting and washed in SOF medium (Caisson Labs, IVL03, USA) supplemented with 1\% (v/v) BME-essential amino acids, $1 \%(\mathrm{v} / \mathrm{v})$ MEM non-essential amino acids, $50 \mu \mathrm{g} / \mathrm{ml}$ gentamycin and $6 \mathrm{mg} / \mathrm{ml} \mathrm{BSA}$. They were then allocated to $50 \mu \mathrm{l}$ drop of SOF medium (25 embryos/ drop). The incubation conditions were humidified by $5 \% \mathrm{O}_{2}, 5 \% \mathrm{CO}_{2}$, and $90 \% \mathrm{~N}_{2}$ at $38.5^{\circ} \mathrm{C}$. The culture was continued until 7-8 days post-fertilization.

\section{Blastocyst staining}

Blastocysts were transferred from culture medium and wash two times in $100 \mu \mathrm{l}$ drop of $1 \%$ PBSpolyvinylpyrrolidone (PVP), fixed in alcohol, washed three times in 1\% PBS-PVP, stained in Hoechst 33342 solution for 10 minutes, washed three times in $1 \%$ PBSPVP. The blastocysts were mounted on the slides and examined them by fluorescent microscope.

\section{$R N A$ isolation and reverse transcription}

All embryos were washed in $0.1 \%$ PBS-PVA. Then, the embryos (5 blastocyst: day 7) were placed in an Eppendorf tube containing $5 \mu \mathrm{l}$ of $0.1 \%$ PBS-PVA and stored at $-80^{\circ} \mathrm{C}$ (three replicates in each group) until RNA extraction. mRNA was extracted from pooled blastocysts from embryos and cDNA was synthesized using the Cells- 
to-cDNA ${ }^{\mathrm{TM}}$ II Kit (Thermo Fisher Scientific, USA; Cat. No. AM1722). Briefly, frozen samples were lysed in $100 \mu \mathrm{l}$ ice-cold Cell Lysis II Buffer. After vortexing and centrifugation, the samples were incubated at $75^{\circ} \mathrm{C}$ for 10 min. For genomic DNA removal, RNA samples were treated with $2 \mu \mathrm{l}$ DNase I per $100 \mu$ l Cell Lysis II Buffer for $30 \mathrm{~min}$ at $37^{\circ} \mathrm{C}$. To inactivate DNase I, the samples were heated at $75^{\circ} \mathrm{C}$ for $5 \mathrm{~min}$. Reverse-transcription reactions were performed with $3 \mu \mathrm{g}$ total RNA, dNTP Mix, Oligo(dT)18 Primer, 10X RT Buffer, RNase Inhibitor in total reaction volume of $20 \mu \mathrm{l}$ for $60 \mathrm{~min}$ at $42^{\circ} \mathrm{C}$, followed by $10 \mathrm{~min}$ at $95^{\circ} \mathrm{C}$ to inactivate the reverse transcriptase. The RNA concentration was determined by spectrophotometry (NanoDrop, Wilmington, DE, USA) using a $1 \mu \mathrm{l}$ sample.

\section{Real-time polymerase chain reaction}

Real-time PCR was performed in $50 \mu \mathrm{l}$ of reaction buffer containing $25 \mu \mathrm{l}$ of SYBR $\AA$ Green Master Mix (Applied Biosystems, USA), $2 \mu$ l each of forward and reverse primer pairs for each gene $(400 \mathrm{nM}), 2.5 \mu \mathrm{l}$ of cDNA ( ng/ $\mu \mathrm{l}), 18.5 \mu \mathrm{l}$ of nuclease-free water. Primer sequences and the approximate sizes of the amplified fragment of all transcripts are listed in Table I. The program used for the amplification of the genes consisted of denaturing at $95^{\circ} \mathrm{C}$ for $10 \mathrm{~min}$ and followed by 45 cycles of PCR (denaturation at $95^{\circ} \mathrm{C}$ for 15 seconds, annealing at $60^{\circ} \mathrm{C}$ for 60 seconds, and extension at $72^{\circ} \mathrm{C}$ for 60 seconds). All reactions were carried out using the LightCycler ${ }^{\circledR} 480$ real time PCR machine (Roche Life Science, USA). The expression of each gene was calculated by following formula according to Schmittgen and Livak (2008):

$2^{-\Delta \Delta \mathrm{CT}}=\{(\mathrm{CT}$ gene of interest-CT internal control $)$ treated sample - (CT gene of interest - CT internal control) control sample\}

\section{Statistical analysis}

Statistical analysis of data from at least seven replicates for each treatment comparison was carried out using the SPSS ver. 21 software package (SPSS Inc., Chicago, IL, USA). Data were first evaluated using the KolmogrovSmirnov normalization test. The means of maturation and cleavage rates, different stages of in vitro development and relative gene expression in all groups were compared by one-way analysis of variance (ANOVA) and post-LSD Dunnett's test. Three replicates of gene expression of all genes were used.

Table I.- Details of primer sequences and fragment sizes of genes used for RT-PCR.

\begin{tabular}{|c|c|c|c|c|}
\hline Functions & Symbol gene & Gene & Primer sequence (5-3) & Fragment size (bp) \\
\hline $\begin{array}{l}\text { Endogenous } \\
\text { control }\end{array}$ & H2AFZ & H2A histone family, member $\mathrm{Z}$ & $\begin{array}{l}\text { (F) AGGACGACTAGCCATGGACGTGTG } \\
\text { (R) CCACCACCAGCAATTGTAGCCTTG }\end{array}$ & 212 \\
\hline \multirow[t]{3}{*}{$\begin{array}{l}\text { Embryo } \\
\text { development }\end{array}$} & LAMA1 & Laminin, Alpha 1 & $\begin{array}{l}\text { (F) CCCTGCCAGCAATGCACACATC } \\
\text { (R) TCGGATGCCGTTCTGTTGAAGG }\end{array}$ & 341 \\
\hline & IL6 & Interleukin-6 & $\begin{array}{l}\text { (F) CGCCTTCACTCCATTCGCTGTC } \\
\text { (R) CGCCTGATTGAACCCAGATTGG }\end{array}$ & 307 \\
\hline & FGF4 & Fibroblast Growth Factor 4 & $\begin{array}{l}\text { (F) AACGTGAGCATCGGCTTCCACC } \\
\text { (R) TTGCTCAGGGCGATGAACATGC }\end{array}$ & 284 \\
\hline \multirow[t]{2}{*}{ Apoptosis } & BAX & BCL2-associated X protein & $\begin{array}{l}\text { (F) CTACTTTGCCAGCAAACTGG } \\
\text { (R) TCCCAAAGTAGGAGAGGA }\end{array}$ & 158 \\
\hline & Bcl-2 & B-cell CLL/lymphoma 2 & $\begin{array}{l}\text { (F) GCCGAGATGTCCAGTCAGC } \\
\text { (R) GACGCTCTCCACACACATGAC }\end{array}$ & 150 \\
\hline Stress & HSPB1 & Heat shock protein beta-1 & $\begin{array}{l}\text { (F) TCCCTGGACGTCAACCACTTCG } \\
\text { (R) AGGTTTGGCGGGTGAGGATGTC }\end{array}$ & 391 \\
\hline
\end{tabular}

The primers were reported by Sanna (2009) and Ebrahimi et al. (2010).

Table II.- Effect of sheep follicular fluid on maturation rate, cleavage rate and blastocyst rate of sheep embryos.

\begin{tabular}{|c|c|c|c|c|c|}
\hline $\begin{array}{l}\text { Conc. of follicular } \\
\text { fluid }\end{array}$ & $\begin{array}{l}\text { No. of cultured } \\
\text { oocytes (n)* }\end{array}$ & $\begin{array}{c}\text { Maturation } \\
\text { rate }(\%) \\
\end{array}$ & $\begin{array}{l}\text { Cleavage } \\
\text { rate }(\%)\end{array}$ & $\begin{array}{c}\text { Blastocyst } \\
\text { rate }(\%) \\
\end{array}$ & $\begin{array}{c}\text { Total cells of } \\
\text { blastocyst }\end{array}$ \\
\hline $0 \%($ Group A)** & $626(15)$ & $(61.39 \pm 3.50) \mathrm{a}$ & $(64.53 \pm 3.42) a$ & $(21.03 \pm 1.85) \mathrm{a}$ & $(129.6 \pm 8.08) \mathrm{a}$ \\
\hline 10\% (Group B) & $605(13)$ & $(63.95 \pm 1.84) \mathrm{a}$ & $(66.77 \pm 2.68) \mathrm{a}$ & $(36.13 \pm 3.41) b$ & $(125 \pm 8.05) \mathrm{a}$ \\
\hline 20\% (Group C) & $279(7)$ & $(64.08 \pm 6.47) \mathrm{a}$ & $(64.51 \pm 3.89) \mathrm{a}$ & $(22.77 \pm 4.79) \mathrm{a}$ & $(112.3 \pm 13.1) b$ \\
\hline 40\% (Group D) & $299(7)$ & $(36.87 \pm 2.14) b$ & $(51.17 \pm 3.14) b$ & $(11.77 \pm 0.51) \mathrm{a}$ & None \# \\
\hline
\end{tabular}

Data expressed as Mean \pm SEM of the replicates. ${ }^{* *}$ control group; ${ }^{*}(\mathrm{n})$ number of replicates in each group. ${ }^{\mathrm{a}, \mathrm{b}, \mathrm{c}}$, significantly different $(\mathrm{P}<0.05)$. 

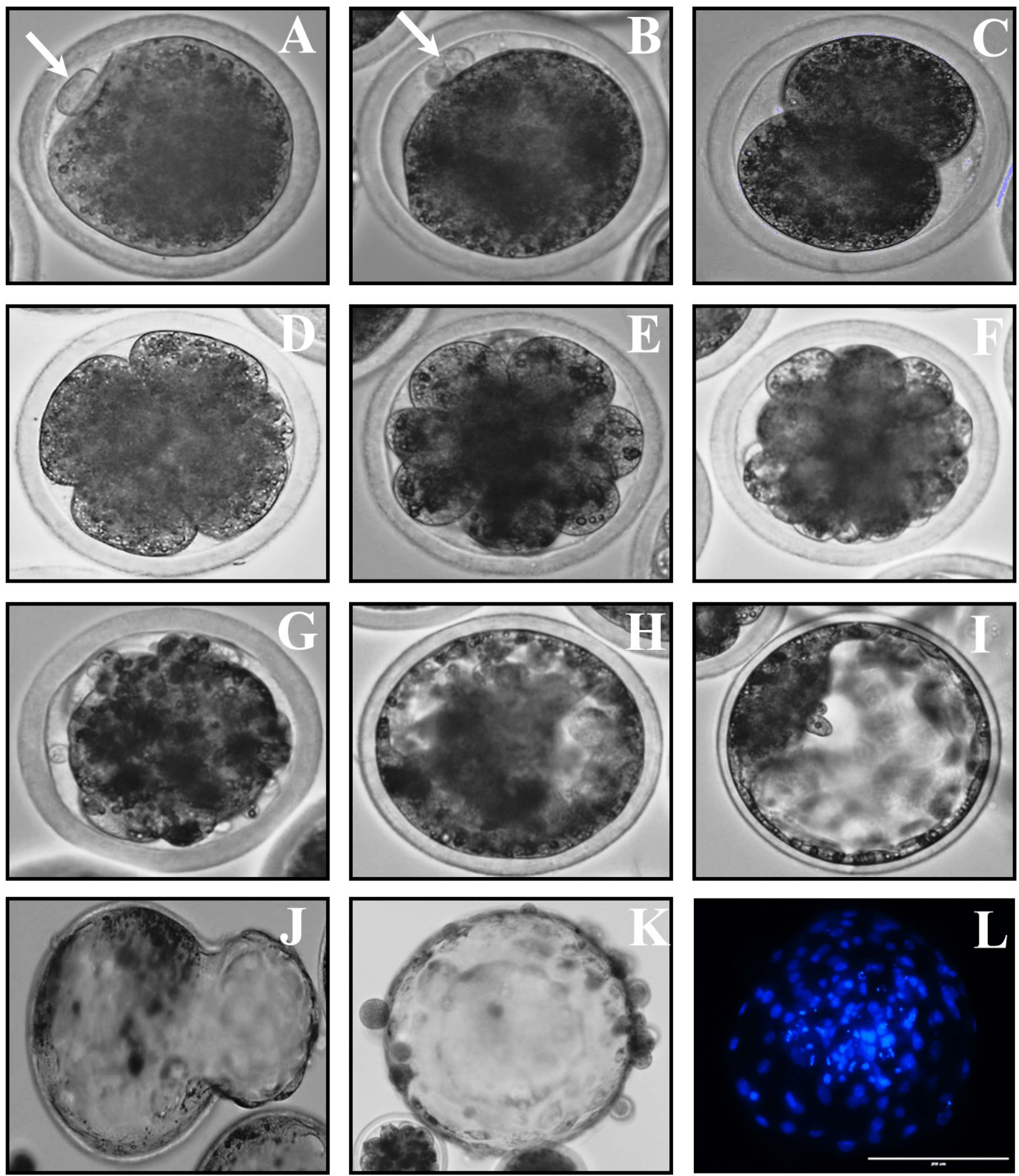

Fig. 1. The different stages of embryonic development of sheep embryos produced in vitro. A, Matured oocyte $\left(\right.$ the arrow $=1^{\text {st }}$ polar body); B, Zygote (the arrow $=2^{\text {nd }}$ polar body); C, 2 cells stage; $D, 4$ cells stage, $€ 8$ cells stage; F, 16 cells stage; G, Morula stage; H, early blastocyst I, expanded blastocyst; J, hatching blastocyst; K, hatched blastocyst; L, blastocyst on day 7 stained with Hoechst. 


\section{RESULTS}

Effect of SFF on maturation, cleavage and hatching rate of blastocyst

The different stages of sheep embryos produced in vitro are summarized in Figure 1. In this experiment, maturation rate, cleavage rate, blastocyst rate and total cells of blastocyst were observed for oocytes that matured in different concentrations of SFF. There were non-significant $(\mathrm{P}>0.05)$ differences in maturation and cleavage rates in groups supplemented with $20 \%$ and $40 \%$ SFF when compared with the control group. However, the maturation and cleavage rates were significantly $(\mathrm{P}<0.05)$ declined in group D when compered with all other groups. On the other hand, the blastocyst rate was significantly higher $(\mathrm{P}<0.05)$ in embryos that obtained from oocytes matured in $10 \%$ of SFF when compared with the control (Group A; 0\% SFF), 20\% SFF (Group C) and 40\% SFF (Group D) supplemented groups. In addition, there was a significant decrease in the total cells of blastocyst in group $\mathrm{C}$ when compared with other groups (Table II). Furthermore, there was a significant increase in blastocyst hatching rate in group B when compared with the other groups as depicted in Figure 2.

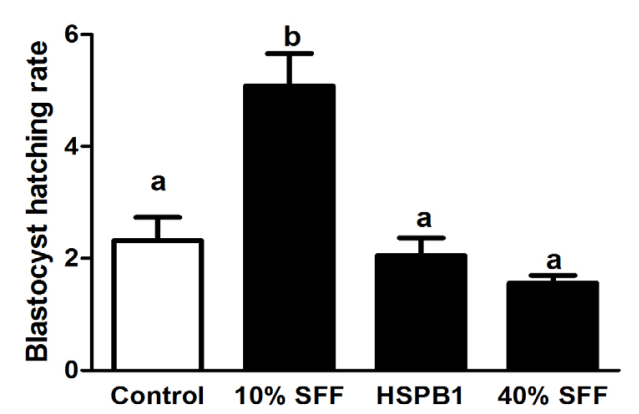

Fig. 2. Effect of sheep follicular fluid on hatching rate of blastocyst. Data are expressed as Mean \pm SEM. Different superscript $(\mathrm{a}, \mathrm{b}, \mathrm{c})$ within columns are significantly different, $(\mathrm{P}<0.05)$.

\section{Effect of SFF on the expression levels of genes related to} apoptosis

The transcripts of Bax and Bcl-2 genes were detected in day7 blastocyst originating from oocytes matured in different treated groups. As depicted in Figure 3, the real time PCR results for the expression of pro-apoptotic gene Bax was highest in the groups supplemented with 20 and $40 \% \mathrm{SFF}$, whereas the expression of anti-apoptotic gene Bcl-2 was only highest in the $40 \%$ SFF supplemented group. In addition, the ratio of $\mathrm{Bax}$ to $\mathrm{Bcl}-2$ was significantly higher $(\mathrm{P}<0.05)$ in the embryos that derived from oocytes matured in $20 \%$ and $40 \%$ of follicular fluid.

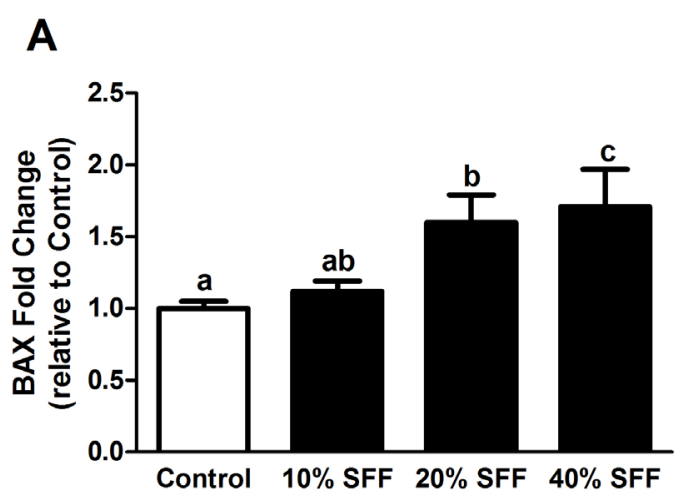

B

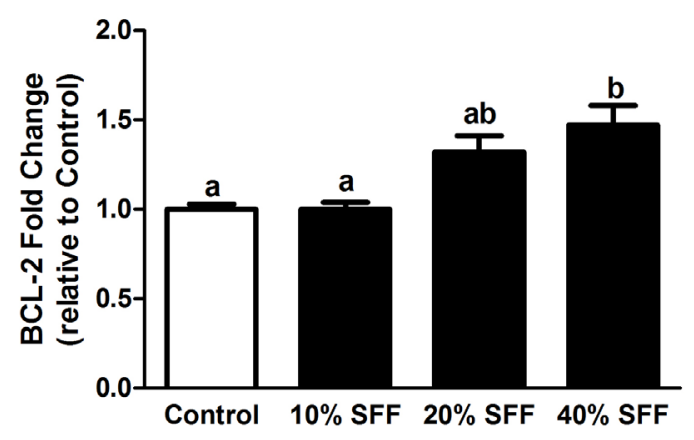

C

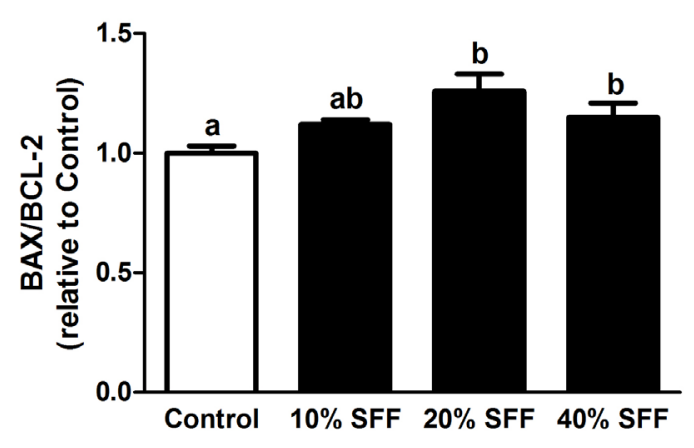

Fig. 3. Effect of sheep follicular fluid on BAX (A), BCL2 gene expression(B) and BAX/BCL-2 (C) ratio of sheep embryos. Data are expressed as Mean \pm SEM. Different superscript $(\mathrm{a}, \mathrm{b}, \mathrm{c})$ within columns are significantly different, $(\mathrm{P}<0.05)$.

Effect of SFF on the expression levels of genes related to stress (HSPB1)

The gene expression of HSBP1 was determined in day7 blastocyst originating from oocytes matured in different treatments (Fig. 4). HSPB1 expression was a significantly higher in the group supplemented with $20 \%$ SFF while showed non-significant changes in the groups supplemented with either 10 or $40 \%$ SFF when compared with the control group. 


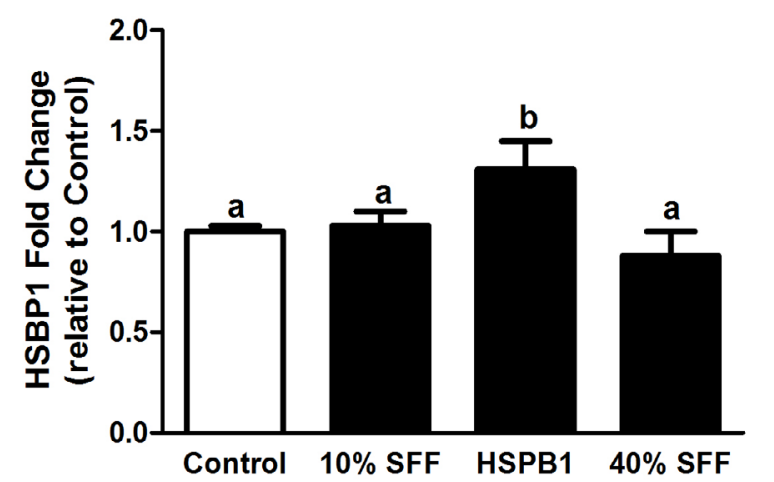

Fig. 4. Effect of sheep follicular fluid on HSBP1gene expression of sheep embryos. Data are expressed as Mean \pm SEM. Different superscript $(\mathrm{a}, \mathrm{b}, \mathrm{c})$ within columns are significantly different, $(\mathrm{P}<0.05)$.

Effect of SFF on the expression levels of genes related to embryo development (FGF-4, IL-6 and LAMA1)

The transcripts of FGF-4, IL-6 and LAMA1 genes were detected in day 7 blastocyst originating from oocytes matured in different groups. Relative expression of analyzed genes are represented in Figure 5. The relative expression of mRNA FGF-4, IL-6 and LAMA1 genes did not differ between groups.

The findings of the study are summarized in Table III.

Table III.- A summary of the effect of follicular fluid on all parameters in this study.

\begin{tabular}{lcccc}
\hline Parameters & A & B & C & D \\
\hline Maturation rate & --- & --- & --- & LS \\
Cleavage rate & --- & --- & --- & LS \\
Blastocyst rate & --- & HS & --- & --- \\
Hatching rate of Blastocyst & --- & HS & --- & --- \\
Total cells of Blastocyst & --- & --- & --- & --- \\
Bax gene expression & --- & --- & HS & HS \\
Bcl-2 gene expression & --- & --- & --- & HS \\
Bax Bcl-2 ratio & --- & --- & HS & HS \\
HSPB1 gene expression & --- & --- & --- & HS \\
LAMA1 gene expression & --- & --- & --- & --- \\
IL-6 gene expression & --- & --- & --- & --- \\
FGF4 gene expression & --- & --- & --- & --- \\
\hline
\end{tabular}

*High or low significant compare to control. SFF, sheep follicular fluid; A, conrol; B, 10\% SFF; C, 20\% SFF; D, 40\% SFF; HS, high significant; LS, low significant.

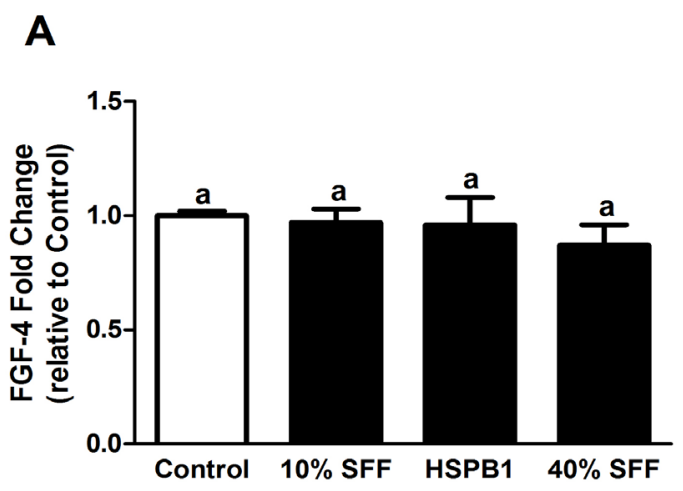

B
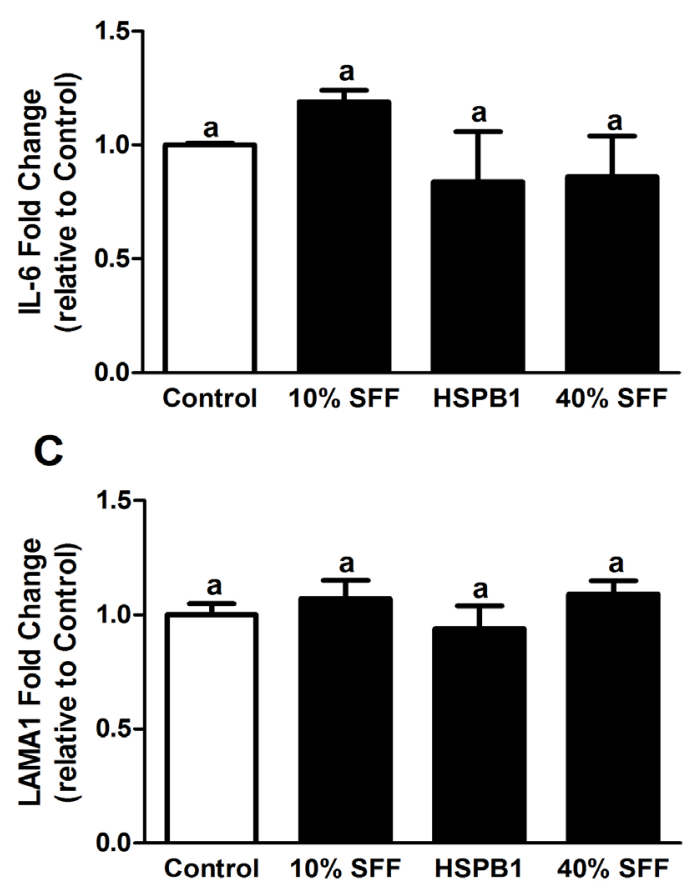

Fig. 5. Effect of sheep follicular fluid on FGFBP-4 (A), IL-6 (B) and LAMA1 (C) gene expression of sheep embryos. Data are expressed as Mean \pm SEM. Different superscript $(\mathrm{a}, \mathrm{b}, \mathrm{c})$ within columns are significantly different, $(\mathrm{P}<0.05)$.

\section{DISCUSSION}

It has been observed that the embryos produced in vivo are of high quality and less apoptosis than those produced in vitro (Pomar et al., 2005; Melka et al., 2010), and the major reason that might contribute to depress oocyte and embryo competence is the in vitro conditions (Wohlres-Viana et al., 2011). In this study, we have used different concentrations of SFF in an attempt to optimize the in vitro conditions of oocyte maturation to be closer to the in vivo status. Some reports have shown high maturation rate in horse oocytes 
that matured in pure follicular fluid (Dell'Aquila et al., 1997; Bogh et al., 2002). On the contrary, in our study, the lowest maturation and cleavage rate was shown in the group of maturation medium supplemented with $40 \% \mathrm{SFF}$. This result in sheep is similar to the report of Cruz et al. (2014) in bovine. They as well as others have observed that high concentrations of FF in the maturation medium reduce maturation rate, cleavage rate, blastocyst rate and cell number of ICM (Avery et al., 2003; Cruz et al., 2014). The low blastocyst rate obtained using high concentrations of FF might be affected by dilution and sudden change of the in vitro media that may negatively interfere with the maturation pathways (Cruz et al., 2014). Furthermore, we found that the hatching rate of blastocyst was significantly higher in the group that has less amount of follicular fluid than other groups. It is well established that the hatching of blastocyst is the most important factor for embryo to implant in uterus (Huisman et al., 2000; Hammadeh et al., 2011; Thompson et al., 2013). And the main factor affecting on the blastocyst yield and implantation rate is the oocyte competence (Lonergan et al., 2003). The composition of maturation media may improve blastocyst yield without increasing the total cells of embryo (Warzych et al., 2007), as observed in group B compare to control in this study.

Additionally, several studies have suggested that modification of the in vitro maturation media can be associated with changes in gene expression not only in oocyte but also in blastocyst (Rizos et al., 2002; Lonergan et al., 2003; Wrenzycki et al., 2005; Nemcova et al., 2006; Warzych et al., 2007; Heinzmann et al., 2011; Diederich et al., 2012; Boruszewska et al., 2015). To characterize the quality of embryos developed from oocytes matured in different media, we compared the relative expression of six genes in sheep blastocyst. Obviously, apoptosis detection is a useful tool to find out the viability of early embryonic development and to define consequences of stress impacts on in vitro maturation of oocytes (Melka et al., 2010; Bakri et al., 2016). Hence, BCL2-associated X protein (Bax) and B-cell CLL/lymphoma 2 (Bcl-2) were chosen in order to study suitable amount of FF for oocyte maturation. Based on our analysis of relative expression of apoptotic genes (Bax and Bcl-2), the embryos that obtained from IVM with large amount of follicular fluid (20\% SFF and 40\% SFF) have lower viability than other embryos. It is well known that suboptimal conditions during in vitro culture may impair embryo quality (Pomar et al., 2005). However, using the ratio of Bcl-2/Bax alone cannot predict the potential of in vitro embryo development (Praveen-Chakravarthi et al., 2015). Thus, the heat shock protein beta 1 (HSPB1) gene was chosen to determine this potential. This study found that HSPB1 high expression is located in blastocysts derived from oocytes matured in medium with $20 \%$ SFF. This observations agree with our findings in the Bcl-2 gene and with decreasing the total cells of blastocyst in same group. Mishra et al. (2017) reported that sheep embryos produced in vitro are highly sensitive to culture condition, which alters the expression level of apoptotic and antioxidant enzyme genes. Moreover, It was documented that HSPB1 and $\mathrm{Bcl}-2$ genes protect the cell from apoptosis during stress conditions by using different pathways (Paul and Arrigo, 2000; Fulda et al., 2010; Banerjee et al., 2011; Acunzo et al., 2012; Liu et al., 2013).

Fibroblast growth factor-4 (FGF4), Laminin $\alpha 1$ (LAMA1) and Interleukin-6 (IL6) genes are known to have specific functions through early embryo development (Desai et al., 1999; Hallmann et al., 2005; Sanna, 2009; Valdez-Magana et al., 2014). No significant differences in relative expression of FGF4, LAMA1 and IL6 genes were found between groups treated with different concentrations of SFF. Previous studies revealed the role of paracrine signals that trigger positive feed-back loops promoting cellular specification (Arnold and Robertson, 2009). FGF4 has been reported to play a central role in promoting trophoblast proliferation (Chen et al., 2009) and in the development and maintenance of the trophoblast stem cell (Guzman-Ayala et al., 2004). Although the stress and apoptosis related genes were affected by SFF supplementation, FGF4, LAMA1 and IL-6 showed nonsignificant changes.

\section{CONCLUSION}

In conclusion, the present study showed that supplementation of the in vitro maturation (IVM) media with $10 \%$ sheep follicular fluid produced the best rate of blastocyst development. At this concentration, the sheep follicular fluid modulated genes related to apoptosis and stress whereas exerted no effect on the genes of FGF-4, IL-6 and LAMA1.

\section{ACKNOWLEDGEMENT}

The project was supported by the Research Center, College of science, King Saud University.

\section{Statement of conflict of interest}

Authors have declared no conflicts of interest.

\section{REFERENCES}

Acunzo, J., Katsogiannou, M. and Rocchi, P., 2012. Small heat shock proteins hsp27 (hspb1), alphabcrystallin (hspb5) and hsp22 (hspb8) as regulators 
of cell death. Int. J. Biochem. Cell Biol., 44: 16221631. https://doi.org/10.1016/j.biocel.2012.04.002

Ali, A., Coenen, K., Bousquet, D. and Sirard, M.A., 2004. Origin of bovine follicular fluid and its effect during in vitro maturation on the developmental competence of bovine oocytes. Theriogenology, 62: 1596-1606. https://doi.org/10.1016/j. theriogenology.2004.03.011

Arnold, S.J. and Robertson, E.J., 2009. Making a commitment: Cell lineage allocation and axis patterning in the early mouse embryo. Nat. Rev. Mol. Cell Biol., 10: 91-103. https://doi.org/10.1038/ nrm2618

Avery, B., Strobech, L., Jacobsen, T., Bogh, I.B. and Greve, T., 2003. In vitro maturation of bovine cumulus-oocyte complexes in undiluted follicular fluid: Effect on nuclear maturation, pronucleus formation and embryo development. Theriogenology, 59: 987-999. https://doi. org/10.1016/S0093-691X(02)01139-1

Bakri, N.M., Ibrahim, S.F., Osman, N.A., Hasan, N., Jaffar, F.H., Rahman, Z.A. and Osman, K., 2016. Embryo apoptosis identification: Oocyte grade or cleavage stage? Saudi J. biol. Sci., 23: S50-55. https://doi.org/10.1016/j.sjbs.2015.10.023

Banerjee, S., Lin, C.F., Skinner, K.A., Schiffhauer, L.M., Peacock, J., Hicks, D.G., Redmond, E.M., Morrow, D., Huston, A., Shayne, M., Langstein, H.N., Miller-Graziano, C.L., Strickland, J., O’Donoghue, L. and De, A.K., 2011. Heat shock protein 27 differentiates tolerogenic macrophages that may support human breast cancer progression. Cancer Res., 71: 318-327. https://doi.org/10.1158/00085472.CAN-10-1778

Bogh, I.B., Bezard, J., Duchamp, G., Baltsen, M., Gerard, N., Daels, P. and Greve, T., 2002. Pure preovulatory follicular fluid promotes in vitro maturation of in vivo aspirated equine oocytes. Theriogenology, 57: 1765-1779. https://doi.org/10.1016/S0093691X(02)00650-7

Boruszewska, D., Sinderewicz, E., Kowalczyk-Zieba, I., Grycmacher, K. and Woclawek-Potocka, I., 2015. The effect of lysophosphatidic acid during in vitro maturation of bovine cumulus-oocyte complexes: Cumulus expansion, glucose metabolism and expression of genes involved in the ovulatory cascade, oocyte and blastocyst competence. Reprod. Biol. Endocrinol., 13: 44. https://doi.org/10.1186/ s12958-015-0044-X

Chen, A.E., Egli, D., Niakan, K., Deng, J., Akutsu, H.,
Yamaki, M., Cowan, C., Fitz-Gerald, C., Zhang, K., Melton, D.A. and Eggan, K., 2009. Optimal timing of inner cell mass isolation increases the efficiency of human embryonic stem cell derivation and allows generation of sibling cell lines. Cell Stem Cell, 4: 103-106. https://doi.org/10.1016/j. stem.2008.12.001

Chi, H.J., Kim, D.H., Koo, J.J. and Chang, S.S., 1998. The suitability and efficiency of human follicular fluid as a protein supplement in human in vitro fertilization programs. Fertil. Steril., 70: 871-877. https://doi.org/10.1016/S0015-0282(98)00313-6

Cognie, Y., Baril, G., Poulin, N. and Mermillod, P., 2003. Current status of embryo technologies in sheep and goat. Theriogenology, 59: 171-188. https://doi. org/10.1016/S0093-691X(02)01270-0

Coleman, N.V., Shagiakhmetova, G.A., Lebedeva, I.Y., Kuzmina, T.I. and Golubev, A.K., 2007. In vitro maturation and early developmental capacity of bovine oocytes cultured in pure follicular fluid and supplementation with follicular wall. Theriogenology, 67: 1053-1059. https://doi. org/10.1016/j.theriogenology.2006.10.019

Cruz, M.H.C., Saraiva, N.Z., Cruz, J.F.D., Oliveira, C.S., Collado, M.D., Fernandes, H., Castro, F.C.D. and Garcia, J.M., 2014. Effect of follicular fluid supplementation during in vitro maturation on total cell number in bovine blastocysts produced in vitro. Rev. Brasil. Zootec., 43: 120-126. https://doi. org/10.1590/S1516-35982014000300003

Dell'Aquila, M.E., Cho, Y.S., Minoia, P., Traina, V., Lacalandra, G.M. and Maritato, F., 1997. Effects of follicular fluid supplementation of invitro maturation medium on the fertilization and development of equine oocytes after in-vitro fertilization or intracytoplasmic sperm injection. Human Reprod., 12: 2766-2772. https://doi. org/10.1093/humrep/12.12.2766

Desai, N., Scarrow, M., Lawson, J., Kinzer, D. and Goldfarb, J., 1999. Evaluation of the effect of interleukin-6 and human extracellullar matrix on embryonic development. Human Reprod., 14: 15881592. https://doi.org/10.1093/humrep/14.6.1588

Diederich, M., Hansmann, T., Heinzmann, J., BargKues, B., Herrmann, D., Aldag, P., Baulain, U., Reinhard, R., Kues, W., Weissgerber, C., Haaf, T. and Niemann, H., 2012. DNA methylation and mrna expression profiles in bovine oocytes derived from prepubertal and adult donors. Reproduction, 144: 319-330. https://doi.org/10.1530/REP-12- 
0134

Duarte, A.B., Araujo, V.R., Chaves, R.N., Silva, G.M., Magalhaes-Padilha, D.M., Satrapa, R.A., Donato, M.A., Peixoto, C.A., Campello, C.C., Matos, M.H., Barros, C.M. and Figueiredo, J.R., 2012. Bovine dominant follicular fluid promotes the in vitro development of goat preantral follicles. Reprod. Fertil. Develop., 24: 490-500. https://doi. org/10.1071/RD11176

Ebrahimi, B., Valojerdi, M.R., Eftekhari-Yazdi, P. and Baharvand, H., 2010. In vitro maturation, apoptotic gene expression and incidence of numerical chromosomal abnormalities following cryotop vitrification of sheep cumulus-oocyte complexes. J. Assist. Reprod. Genet., 27: 239-246. https://doi. org/10.1007/s10815-010-9401-z

Fulda, S., Gorman, A.M., Hori, O. and Samali, A., 2010. Cellular stress responses: Cell survival and cell death. Int. J. Cell Biol., 2010: 23. https://doi. org/10.1155/2010/214074

Gupta, P.S.P., Ravindra, J.P., Kumar, V.G., Raghu, H.M. and Nandi, S., 2005. Stimulation of in vitro ovine oocyte maturation with a novel peptide isolated from follicular fluid of the buffalo (Bubalus bubalis). Small Rumin. Res., 59: 33-40. https://doi. org/10.1016/j.smallrumres.2004.11.015

Guzman-Ayala, M., Ben-Haim, N., Beck, S. and Constam, D.B., 2004. Nodal protein processing and fibroblast growth factor 4 synergize to maintain a trophoblast stem cell microenvironment. Proc. natl. Acad. Sci. U.S.A., 101: 15656-15660. https:// doi.org/10.1073/pnas.0405429101

Hallmann, R., Horn, N., Selg, M., Wendler, O., Pausch, F. and Sorokin, L.M., 2005. Expression and function of laminins in the embryonic and mature vasculature. Physiol. Rev., 85: 979-1000. https:// doi.org/10.1152/physrev.00014.2004

Hammadeh, M.E., Fischer-Hammadeh, C. and Ali, K.R., 2011. Assisted hatching in assisted reproduction: A state of the art. J. Assist. Reprod. Genet., 28: 119128. https://doi.org/10.1007/s10815-010-9495-3

Heinzmann, J., Hansmann, T., Herrmann, D., Wrenzycki, C., Zechner, U., Haaf, T. and Niemann, H., 2011. Epigenetic profile of developmentally important genes in bovine oocytes. Mol. Reprod. Develop., 78: 188-201. https://doi.org/10.1002/mrd.21281

Huang, W.T., Lu, S.G., Tang, P.C., Wu, S.C., Cheng, S.P. and Ju, J.C., 2002. Biochemical compositions of follicular fluid and the effects of culture conditions on the in vitro development of pig oocytes. Asian-
Australasian J. Anim. Sci., 15: 1403-1411.

Huisman, G.J., Fauser, B.C., Eijkemans, M.J. and Pieters, M.H., 2000. Implantation rates after in vitro fertilization and transfer of a maximum of two embryos that have undergone three to five days of culture. Fertil. Steril., 73: 117-122. https://doi. org/10.1016/S0015-0282(99)00458-6

Ito, M., Iwata, H., Kitagawa, M., Kon, Y., Kuwayama, T. and Monji, Y., 2008. Effect of follicular fluid collected from various diameter follicles on the progression of nuclear maturation and developmental competence of pig oocytes. Anim. Reprod. Sci., 106: 421-430. https://doi. org/10.1016/j.anireprosci.2007.06.003

Iwata, H., Hashimoto, S., Ohota, M., Kimura, K., Shibano, K. and Miyake, M., 2004. Effects of follicle size and electrolytes and glucose in maturation medium on nuclear maturation and developmental competence of bovine oocytes. Reproduction, 127: 159-164. https://doi.org/10.1530/rep.1.00084

Kim, K., Mitsumizo, N., Fujita, K. and Utsumi, K., 1996. The effects of follicular fluid on in vitro maturation, oocyte fertilization and the development of bovine embryos. Theriogenology, 45: 787-799. https://doi. org/10.1016/0093-691X(96)00008-8

Lanzendorf, S.E., Gordon, K., Mahony, M., Boyd, C.A., Neely, B. and Hodgen, G.D., 1996. The effect of coculture on the postfertilization development of in vitro-matured monkey oocytes. Fertil. Steril., 65: 420-425. https://doi.org/10.1016/S00150282(16)58110-2

Larocca, C., Kmaid, S. and Calvo, J., 1993. Effect of follicular fluid and estrous cow serum on maturation, fertilization and development of the bovine oocyte in vitro. Theriogenology, 3: 239-253.

Li, H.J., Liu, D.J., Cang, M., Wang, L.M., Jin, M.Z., Ma, Y.Z. and Shorgan, B., 2009. Early apoptosis is associated with improved developmental potential in bovine oocytes. Anim. Reprod. Sci., 114: 89-98. https://doi.org/10.1016/j.anireprosci.2008.09.018

Liu, S., Dai, X., Cai, L., Ma, X., Liu, J., Jiang, S., Liu, J. and Cui, Y., 2013. Effect of hsp27 on early embryonic development in the mouse. Reprod. Biomed. Online, 26: 491-499. https://doi. org/10.1016/j.rbmo.2013.01.005

Lonergan, P., Rizos, D., Gutierrez-Adan, A., Fair, T. and Boland, M.P., 2003. Oocyte and embryo quality: Effect of origin, culture conditions and gene expression patterns. Reprod. Domest. Anim., 38: $259-267 . \quad$ https://doi.org/10.1046/j.1439- 
0531.2003.00437.x

Masudul, H., Khandoker, M.A.M.Y., Kabiraj, S.K., Asad, L.Y., Fakruzzaman, M. and Tareq, K.M.A., 2012. Effect of goat follicular fluid on in vitro production of embryos in black bengal goats. Iranian J. appl. Anim. Sci., 2: 287-294.

Melka, M.G., Rings, F., Holker, M., Tholen, E., Havlicek, V., Besenfelder, U., Schellander, K. and Tesfaye, D., 2010. Expression of apoptosis regulatory genes and incidence of apoptosis in different morphological quality groups of in vitro-produced bovine preimplantation embryos. Reprod. Domest. Anim., 45: 915-921.

Mishra, A., Reddy, I.J., Gupta, P.S. and Mondal, S., 2017. Expression of apoptotic and antioxidant enzyme genes in sheep oocytes and in vitro produced embryos. Anim. Biotechnol., 28: 18-25. https://doi.org/10.1080/10495398.2016.1193743

Nandi, S., Raghu, H.M., Ravindranatha, B.M., Gupta, P.S. and Sarma, P.V., 2004. In vitro development of buffalo oocytes in media-containing fluids from different size class follicles. Reprod. Domest. Anim., 39: 33-38. https://doi.org/10.1046/j.14390531.2003.00472.x

Nemcova, L., Machatkova, M., Hanzalova, K., Horakova, J. and Kanka, J., 2006. Gene expression in bovine embryos derived from oocytes with different developmental competence collected at the defined follicular developmental stage. Theriogenology, 65: 1254-1264. https://doi. org/10.1016/j.theriogenology.2005.08.006

Paul, C. and Arrigo, A.P., 2000. Comparison of the protective activities generated by two survival proteins: Bcl-2 and hsp27 in 1929 murine fibroblasts exposed to menadione or staurosporine. Exp. Gerontol., 35: 757-766. https://doi.org/10.1016/ S0531-5565(00)00150-9

Pomar, F.J., Teerds, K.J., Kidson, A., Colenbrander, B., Tharasanit, T., Aguilar, B. and Roelen, B.A., 2005. Differences in the incidence of apoptosis between in vivo and in vitro produced blastocysts of farm animal species: A comparative study. Theriogenology, 63: 2254-2268. https://doi. org/10.1016/j.theriogenology.2004.10.015

Praveen-Chakravarthi, V., Kona, S.S.R., Siva-Kumar, A.V.N., Bhaskar, M. and Rao, V.H., 2015. Quantitative expression of antiapoptotic and proapoptotic genes in sheep ovarian follicles grown in vivo or cultured in vitro. Theriogenology, 83: $\quad 590-595$. $\quad$ https://doi.org/10.1016/j. theriogenology.2014.10.024

Rizos, D., Ward, F., Duffy, P., Boland, M.P. and Lonergan, P., 2002. Consequences of bovine oocyte maturation, fertilization or early embryo development in vitro versus in vivo: Implications for blastocyst yield and blastocyst quality. Mol. Reprod. Develop., 61: 234-248. https://doi. org/10.1002/mrd.1153

Sanna, D., 2009. Quality of in vitro ovine embryo production: Lambing rate, body weight and gene expression. Tesi di dottorato in Riproduzione, Produzione e Benessere Animale. Università degli Studi di Sassari. Thesis. pp. 126.

Schmittgen, T.D. and Livak, K.J., 2008. Analyzing realtime pcr data by the comparative $\mathrm{c}(\mathrm{t})$ method. Nat. Protoc., 3: 1101-1108. https://doi.org/10.1038/ nprot.2008.73

Sun, F.J., Holm, P., Irvine, B. and Seamark, R.F., 1994. Effect of sheep and human follicular fluid on the maturation of sheep oocytes in vitro. Theriogenology, 41: 981-988. https://doi. org/10.1016/0093-691X(94)90513-I

Tabatabaei, S. and Mamoei, M., 2011. Biochemical composition of blood plasma and follicular fluid in relation to follicular size in buffalo. Comp. Clin. Pathol., 20: 441-445. https://doi.org/10.1007/ s00580-010-1014-5

Thompson, S.M., Onwubalili, N., Brown, K., Jindal, S.K. and McGovern, P.G., 2013. Blastocyst expansion score and trophectoderm morphology strongly predict successful clinical pregnancy and live birth following elective single embryo blastocyst transfer (eset): A national study. $J$. Assist. Reprod. Genet., 30: 1577-1581. https://doi. org/10.1007/s10815-013-0100-4

Valdez-Magana, G., Rodriguez, A., Zhang, H., Webb, R. and Alberio, R., 2014. Paracrine effects of embryoderived fgf4 and bmp4 during pig trophoblast elongation. Develop. Biol., 387: 15-27. https://doi. org/10.1016/j.ydbio.2014.01.008

Warzych, E., Wrenzycki, C., Peippo, J. and Lechniak, D., 2007. Maturation medium supplements affect transcript level of apoptosis and cell survival related genes in bovine blastocysts produced in vitro. Mol. Reprod. Develop., 74: 280-289. https:// doi.org/10.1002/mrd.20610

Watson, A.J., de Sousa, P., Caveney, A., Barcroft, L.C., Natale, D., Urquhart, J. and Westhusin, M.E., 2000. Impact of bovine oocyte maturation media on oocyte transcript levels, blastocyst development, 
cell number, and apoptosis. Biol. Reprod., 62: $355-$ 364. https://doi.org/10.1095/biolreprod62.2.355

Wohlres-Viana, S., Boite, M.C., Viana, J.H.M., Machado, M.A. and Camargo, L.S.D.A., 2011. Relative expression of mrnas related to cavitation process in bovine embryos produced in vivo and in vitro. Rev. Brasil. Zootec., 40: 124-128. https://doi. org/10.1590/S1516-35982011000100017

Wrenzycki, C., Herrmann, D., Lucas-Hahn, A., Korsawe, K., Lemme, E. and Niemann, H., 2005. Messenger rna expression patterns in bovine embryos derived from in vitro procedures and their implications for development. Reprod. Fertil. Develop., 17: 23-35. https://doi.org/10.1071/RDv17n2Ab236

Young, L.E., Fernandes, K., McEvoy, T.G., Butterwith, S.C., Gutierrez, C.G., Carolan, C., Broadbent, P.J., Robinson, J.J., Wilmut, I. and Sinclair, K.D., 2001. Epigenetic change in igf $2 \mathrm{r}$ is associated with fetal overgrowth after sheep embryo culture. Nat. Genet., 27: 153-154. https://doi.org/10.1038/84769 